\title{
Responses of Seed Yield Components to the Field Practices for Regulating Seed Yield of Smooth Bromegrass (Bromus inermis Leyss.)
}

\author{
Chengming Ou ${ }^{1,+}$, Mingya Wang ${ }^{2,+}$, Longyu Hou ${ }^{3}$, Yangyang Zhang ${ }^{4}$, Ming Sun ${ }^{1}$, Shoujiang Sun ${ }^{1}$, \\ Shangang Jia ${ }^{1}$ and Peisheng Mao ${ }^{1, *(\mathbb{D})}$
}

1 Forage Seed Laboratory, China Agricultural University, Beijing Key Laboratory of Grassland Science, Beijing 100193, China; B20203240983@cau.edu.cn (C.O.); sunmiir@cau.edu.cn (M.S.); b20193040362@cau.edu.cn (S.S.); shangang.jia@cau.edu.cn (S.J.)

2 College of Animal Science and Technology, Hebei Agricultural University, Baoding 071000, China; mingyawang@cau.edu.cn

3 State Key Laboratory of Vegetation and Environmental Change, Institute of Botany, Chinese Academy of Sciences, Beijing 100093, China; houly@ibcas.au.cn

4 China Institute of Animal Science, Chinese Academy of Agricultural Sciences, Beijing 100193, China; yangyangz@cau.edu.cn

* Correspondence: maops@cau.edu.cn; Tel.: +86-010-62733311

+ These authors contributed equally to this work.

check for updates

Citation: Ou, C.; Wang, M.; Hou, L.; Zhang, Y.; Sun, M.; Sun, S.; Jia, S.; Mao, P. Responses of Seed Yield Components to the Field Practices for Regulating Seed Yield of Smooth Bromegrass (Bromus inermis Leyss.). Agriculture 2021, 11, 940. https://doi.org/10.3390/ agriculture11100940

Academic Editor: Hilary Mayton

Received: 19 August 2021

Accepted: 25 September 2021

Published: 28 September 2021

Publisher's Note: MDPI stays neutral with regard to jurisdictional claims in published maps and institutional affiliations.

Copyright: (c) 2021 by the authors. Licensee MDPI, Basel, Switzerland. This article is an open access article distributed under the terms and conditions of the Creative Commons Attribution (CC BY) license (https:/ / creativecommons.org/licenses/by/ $4.0 /)$.

\begin{abstract}
Agronomic practices improve seed yield by regulating seed yield components, and the relationship between seed yield and seed yield components is still unclear in smooth bromegrass (Bromus inermis). To optimize seed production and yield in smooth bromegrass, a five-year field trial was designed with split-split-plot to study the combined effects of row spacing $(30,45,60$, and 75 $\mathrm{cm})$, phosphorus $\left(0,60,90\right.$, and $\left.120 \mathrm{~kg} \mathrm{P} \mathrm{ha}^{-1}\right)$ and nitrogen $\left(0\right.$ and $\left.100 \mathrm{~kg} \mathrm{~N} \mathrm{ha}^{-1}\right)$ on seed yield and seed yield components including fertile tillers $\mathrm{m}^{-2}$ (FTs), spikelets per fertile tiller (SFT), florets per spikelet (FS), and seeds per spikelet (SS). The results showed that FTs as a key factor had a positive effect to seed yield with the biggest pathway coefficient, while SS had a negative effect. Meanwhile, an interaction effect between FTs and SS was observed. FS and SS were increased with phosphorus application under the condition of sufficient nitrogen. In addition, sufficient precipitation at the non-growing season resulted in more FTs in the next year in rain-fed regions. Therefore, the optimum seed yield of smooth bromegrass can be obtained with row spacing $(45 \mathrm{~cm})$, nitrogen $\left(100 \mathrm{~kg} \mathrm{~N} \mathrm{ha}^{-1}\right)$, and phosphorus application (60 $\left.\mathrm{kg} \mathrm{P} \mathrm{ha}^{-1}\right)$.
\end{abstract}

Keywords: fertilization; row spacing; seed yield; seed yield component; smooth bromegrass

\section{Introduction}

Field management practices including seeding, fertilization, irrigation, and weed control, etc., are important factors for a seed grower to improve seed yield. Research on cool-season grasses revealed that agronomic practices, such as plant density, fertilization, and residue management, influenced the level of seed yield and quality [1,2].

Seed yield components consist of fertile tillers $\mathrm{m}^{-2}$ (FTs), spikelets per fertile tiller (SFT), florets per spikelet (FS), and seeds per spikelet (SS), which are significantly related to the seed yield of grass species [3]. Previous studies in smooth bromegrass (Bromus inermis Leyss.), Russian wildrye (Psathyrostachys juncea Nevski), and Siberian wildrye (Elymus sibiricus L.) showed that there was a significant correlation between the FT and seed yield [4-6]. The range of variation for the SFT and FS of perennial ryegrass (Lolium perenne L.) is influenced by the genetic backgrounds during plant growth $[7,8]$. Additionally, agronomic practices can increase the number of FS in perennial ryegrass [9]. The number of SS is limited by self-incompatibility [10], weather at pollination [11], and lodging at flowering [12]. Therefore, 
the relationship between seed yield and yield components needs to be explored further for grass seed production in certain areas.

Plant density is one of the key factors affecting plant growth and seed yield, mainly by regulating the demand for resources such as space, water, nutrient, and light $[13,14]$. The row spacing for the optimum seed yield is varied in different grass species, and even in different regions, as seed development and tiller growing depend on the closing time of the crop canopy $[15,16]$.

Nitrogen, as a massive element restricting the growth and reproduction of crops $[17,18]$, plays an important role in plant growth and seed development [19]. Nitrogen affects the photosynthetic capacity of leaves, tiller formation, spikelet differentiation, and grain quality [20,21]. Insufficient nitrogen application decreases the seed yield, while excessive nitrogen application might cause a low utilization rate, soil pollution, and plant lodging, which consequently decreases the seed yield and quality $[22,23]$. Application of an appropriate amount of nitrogen increases the seed yield through the improved number of FTs and SS in rice (Oryza sativa L.) and wheat (Triticum aestivum L.) [24,25]. Additionally, the variation of FTs in Leymus chinensis is regulated by the timing and rate of nitrogen application [26,27].

Plants take up phosphorus from the soil during the entire growth period and accumulate a large amount of phosphorus in their seeds [28]. Phosphorus deficiency inhibits plant photosynthesis mainly in terms of the reduction in ATP production, Rubisco activity, and RUBP regeneration rate [29,30]. Phosphorus deficiency also inhibits plant root growth and carbohydrate transport, so as to reduce the yield and stand age of perennials [31]. Appropriate phosphorus application can promote the development and growth of the root [32], regulate the distribution of assimilation products, and facilitate flowering and seed physiological maturation [33]. The application of phosphorus fertilizer is beneficial to the accumulation and transfer efficiency of phosphorus from stems and leaves to grains, which is conducive to increasing the seed yield [34]. It has been reported that an application of $18 \mathrm{~kg} \mathrm{P} \mathrm{ha}^{-1}$ increased the seed yields of smooth bromegrass in the soil with available phosphorus at a medium level under rain-fed conditions [35]. Moreover, phosphorus application can also improve the number of SFTs in Siberian wildrye [6]. However, how the seed yield components respond to the field practices for maintaining higher seed yield is still a focused point for the research of seed technological during grass seed production.

Smooth bromegrass, originating from the Eurasian continent, is found in the temperate regions of Asia, Europe, and North America. It is a kind of perennial grass with a high tolerance for drought and cold, and is widely used for pasture cultivation, rangeland improvement, and soil and water conservation in semi-arid regions in China [36,37]. Compared with annual crops, perennial grass has poor performances of reproduction and seed yield [26], which largely depends on soil fertility, environmental factors, and varieties [38]. Previous research on seed production of smooth bromegrass mostly focused on one single factor, for example, row spacing, phosphorus, or nitrogen treatments $[16,35,39,40]$ and no interactive pattern among seed yield components was investigated. In this study, the experiments were designed with a split-splitplot factorial arrangement consisting of row spacing, nitrogen, and phosphorus application to evaluate the interaction pattern among seed yield components and their contributions to the seed yield in smooth bromegrass.

\section{Materials and Methods}

\subsection{Seed Field Location}

The field trials were performed at the Yuershan farm in Hebei Province, China $\left(41^{\circ} 44^{\prime}\right.$ $\mathrm{N}, 116^{\circ} 8^{\prime} \mathrm{E} ; 1455 \mathrm{~m}$ elevation) during the growing seasons of 2014, 2015, 2016, 2017, and 2018. Seed field is located in the semi-arid continental monsoon climate zone, where the monthly mean temperature is stable among years, and precipitation is mainly enriched from May to October (Figure 1). There was $46.48 \mathrm{mg} \mathrm{kg}^{-1}$ available nitrogen (N), $1.33 \mathrm{mg} \mathrm{kg}^{-1}$ available phosphorus (P), $22.99 \mathrm{~g} \mathrm{~kg}^{-1}$ total potassium (K), and $12.82 \mathrm{~g} \cdot \mathrm{kg}^{-1}$ organic matter in the soil $(0 \sim 30 \mathrm{~cm})$ before sowing. 


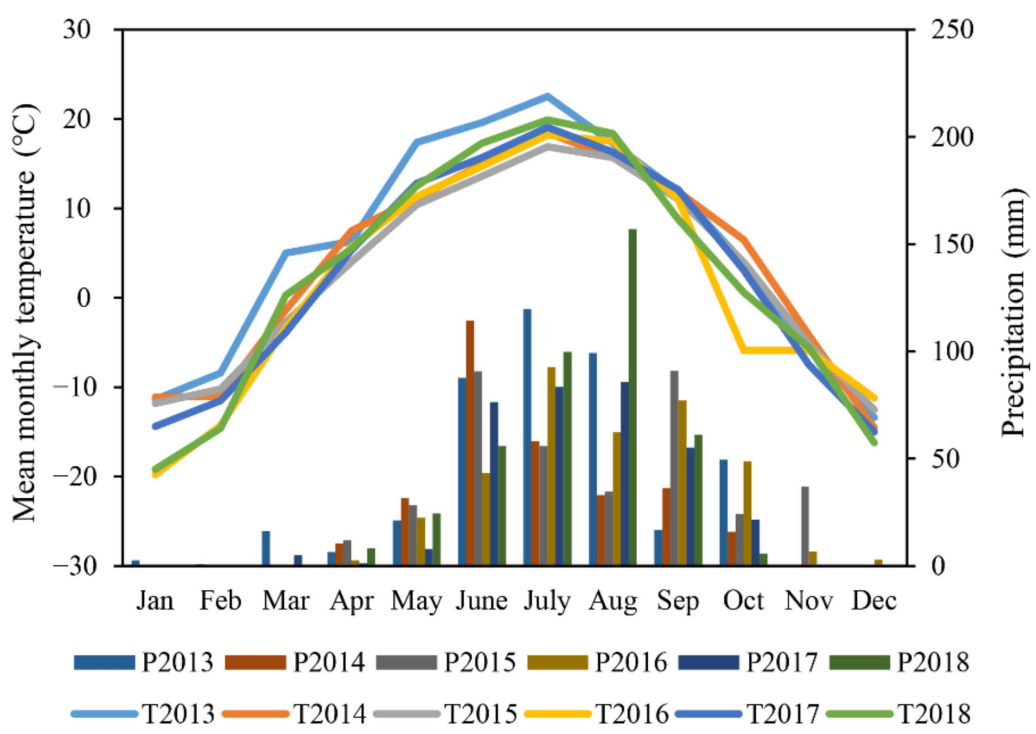

Figure 1. Monthly means of precipitation (mm) and temperature $\left({ }^{\circ} \mathrm{C}\right)$ from 2013 to 2018 in the field located in Yuershan, Hebei Province, China. Bars indicate precipitation (P2013 P2018), and lines indicate temperature (T2013 T2018).

\subsection{Trial Design and Treatments}

Field trials were established by the seeding of Yuanye smooth bromegrass (seeding rate $35.2 \mathrm{~kg} \mathrm{ha}^{-1}$ ) in July 2013 with a split-split-plot design, and the plots were arranged in a randomized complete block design with four replicates. Row spacing $(\mathrm{R})$, nitrogen $(\mathrm{N})$, and phosphorus $(\mathrm{P})$ levels were arranged as main plot, subplot, and sub-subplot, respectively. The size of the sub-subplot experimental unit was $5 \mathrm{~m} \times 4 \mathrm{~m}$. Row spacing treatment had four levels, i.e., 30 (R1), 45 (R2), 60 (R3), and 75 (R4) cm. The four levels of P application were 0 (P1), 60 (P2), 90 (P3), and 120 (P4) kg P ha ${ }^{-1}$ with calcium superphosphate (12\% $\mathrm{P}_{2} \mathrm{O}_{5}$ ) broadcasted together with seeds. The two levels of $\mathrm{N}$ application were $0(\mathrm{~N} 1)$ and $100(\mathrm{~N} 2) \mathrm{kg} \mathrm{N} \mathrm{ha}^{-1}$, and urea $(46 \% \mathrm{~N})$ was applied at the tillering stage, from 2014 to 2018. Seed development entered the milk stage in early July and the hard stage in late July. The field experiment ended in August 2018.

\subsection{Seed Sampling and Analysis}

\subsubsection{Seed Yield Components}

Fertile tillers $\mathrm{m}^{-2}$ were measured by randomly selecting a 1-m-row sample in each plot at milk stage. Thirty fertile tillers and thirty spikelets were selected randomly to determine the number of spikelets per fertile tiller, florets per spikelet, and seeds per spikelet at the milk stage.

\subsubsection{Seed Yield}

Mature seeds were carefully hand-harvested from 1-m-row plants in each plot at the end of July; after, they were air dried (at $20-25^{\circ} \mathrm{C}$, for $2-3$ days), threshed, and cleaned by hand. Seed yield $\left(\mathrm{kg} \mathrm{ha}^{-1}\right)$ was calculated by weighing samples on the scale $( \pm 0.001 \mathrm{gr})$.

\subsection{Statistical Analysis}

Excel 2010 software was used for data input and collation. Experiment data from the split-split plot design were analyzed based on the generalized linear model (GLM) in SPSS version 23.0 (SPSS, IBM, Inc., Chicago, IL, USA). Treatment means were used for Duncan's new multiple range test, at a significance level of 0.05 . The variables of year, row spacing, nitrogen, and phosphorus application were considered as fixed effects, and block was considered a random effect. Year was treated as a repeated measure variable. The variables were compared among different $\mathrm{P}$ application levels with a combination with $\mathrm{N} 0$ and N1, 
in One-way ANOVA analysis at a significance level of 0.05 . One-way ANOVA analysis was also conducted to assess the effect of harvested year. The relationships between seed yield and yield components were examined across years by using Pearson's correlation analysis across years. Multiple stepwise regression analysis was used to evaluate pathways from management factors to yield components and seed yield.

\section{Results}

\subsection{Effects of Harvested Year, Row Spacing, and Fertilizer Application on Seed Yield and Yield Components in Smooth Bromegrass}

The results of variance analysis showed that there were significant $(p<0.05)$ effects for the harvested year, row spacing, and N/P application on seed yield and all the seed yield components, but there was no significant effect for P application on SFT (Table 1). The interaction of row spacing and $\mathrm{N}$ application $(\mathrm{R} \times \mathrm{N})$ significantly affected the seed yield components of FTs $(p<0.05)$, SFT $(p<0.05)$, and SS $(p<0.01)$. FS, SS, and seed yield were significantly $(p<0.01)$ affected by the interaction of $\mathrm{N}$ and $\mathrm{P}$ application $(\mathrm{N} \times \mathrm{P})$. However, there were no significant effects for the interaction of row spacing and $\mathrm{P}$ application $(\mathrm{R} \times \mathrm{P})$, and $\mathrm{R} \times \mathrm{N} \times \mathrm{P}$ on seed yield and yield components.

Table 1. ANOVA results for harvested year, row spacing, and N/P application on seed yield and seed yield components in smooth bromegrass.

\begin{tabular}{|c|c|c|c|c|c|}
\hline $\begin{array}{l}\text { Source of } \\
\text { Variation }\end{array}$ & $\begin{array}{l}\text { Fertile Tillers } \mathrm{m}^{-2} \\
\text { (FTs) }\end{array}$ & $\begin{array}{l}\text { Spikelets Per } \\
\text { Fertile Tiller } \\
\text { (SFT) }\end{array}$ & $\begin{array}{c}\text { Florets Per } \\
\text { Spikelet (FS) }\end{array}$ & $\begin{array}{c}\text { Seeds Per } \\
\text { Spikelet (SS) }\end{array}$ & Seed Yield (kg ha $\left.{ }^{-1}\right)$ \\
\hline Harvest year & $* *$ & ** & $* *$ & $* *$ & $* *$ \\
\hline $\mathrm{R}$ & $* *$ & $* *$ & $* *$ & $* *$ & $* *$ \\
\hline $\mathrm{N}$ & $* *$ & $* *$ & ** & $* *$ & $* *$ \\
\hline $\mathrm{P}$ & * & ns & $* *$ & $* *$ & $* *$ \\
\hline $\mathrm{R} \times \mathrm{N}$ & $*$ & $*$ & ns & $* *$ & ns \\
\hline $\mathrm{R} \times \mathrm{P}$ & ns & ns & ns & ns & ns \\
\hline $\mathrm{N} \times \mathrm{P}$ & ns & ns & $* *$ & $* *$ & $* *$ \\
\hline $\mathrm{R} \times \mathrm{N} \times \mathrm{P}$ & ns & ns & ns & ns & ns \\
\hline
\end{tabular}

${ }^{*}$ significant at 0.05 level; ${ }^{* *}$ significant at 0.01 level; $n s$, no significance.

\subsection{Effects of Different Treatments of Row Spacing, and N/P Application}

The FT values decreased significantly $(p<0.05)$ with the increase in row spacing from 30 to $75 \mathrm{~cm}$, while SFT, FS, and SS presented the increasing tendency (Table 2). The FT values in the treatments of R1 $(30 \mathrm{~cm})$ and $\mathrm{R} 2(45 \mathrm{~cm})$ were significantly $(p<0.05)$ higher than those in R3 $(60 \mathrm{~cm})$ and R4 $(75 \mathrm{~cm})$. The seed yield, with a similar trend to FTs, firstly increased and then decreased, with the highest $\left(527.67 \mathrm{~kg} \cdot \mathrm{ha}^{-1}\right)$ at the R2 treatment. Furthermore, there was a significant increase in the seed yield and yield components with more $\mathrm{N}$ and $\mathrm{P}$ application (Table 2). All the seed yield components significantly $(p<0.05)$ increased with N1 application (100 $\left.\mathrm{kg} \mathrm{N} \mathrm{ha}^{-1}\right)$ compared to those with $\mathrm{N} 0\left(0 \mathrm{~kg} \mathrm{~N} \mathrm{ha}^{-1}\right)$. $\mathrm{P}$ application significantly $(p<0.05)$ increased the seed yield and improved FTs, FS, and SS, except for SFT, but there were no significant differences among P2, P3, and P4. 
Table 2. Effects of row spacing and N/P application on seed yield and seed yield components in smooth bromegrass.

\begin{tabular}{|c|c|c|c|c|c|}
\hline Treatments & $\begin{array}{l}\text { Fertile Tillers } \mathrm{m}^{-2} \\
\text { (FTs) }\end{array}$ & $\begin{array}{l}\text { Spikelets Per } \\
\text { Fertile Tiller } \\
\text { (SFT) }\end{array}$ & $\begin{array}{c}\text { Florets Per } \\
\text { Spikelet (FS) }\end{array}$ & $\begin{array}{c}\text { Seeds Per } \\
\text { Spikelet (SS) }\end{array}$ & Seed Yield (kg ha $\left.{ }^{-1}\right)$ \\
\hline \multicolumn{6}{|c|}{ Row spacing $(\mathrm{cm})$} \\
\hline R1 (30) & $328^{a, \dagger}$ & $15.61^{\mathrm{d}}$ & $5.10^{\mathrm{b}}$ & $3.27^{b}$ & $498.51^{\mathrm{a}, \mathrm{b}}$ \\
\hline R2 (45) & $331^{\mathrm{a}}$ & $17.37^{\mathrm{c}}$ & $5.12^{b}$ & $3.34^{b}$ & $527.67^{\mathrm{a}}$ \\
\hline R3 (60) & $289^{b}$ & $18.03^{\mathrm{b}}$ & $5.35^{\mathrm{a}}$ & $3.52^{\mathrm{a}}$ & $496.98^{a b}$ \\
\hline R4 (75) & $222^{c}$ & $18.80^{\text {a }}$ & $5.38^{\mathrm{a}}$ & $3.54^{\mathrm{a}}$ & $477.76^{\mathrm{b}}$ \\
\hline \multicolumn{6}{|c|}{$\mathrm{N}$ application $\left(\mathrm{kg} \mathrm{N} \mathrm{ha}^{-1}\right)$} \\
\hline No $(0)$ & $201^{b}$ & $16.00^{\mathrm{b}}$ & $4.88^{\mathrm{b}}$ & $3.07^{b}$ & $265.44^{b}$ \\
\hline N1 (100) & $382^{\mathrm{a}}$ & $18.76^{\mathrm{a}}$ & $5.59^{\mathrm{a}}$ & $3.75^{\mathrm{a}}$ & $741.94^{\mathrm{a}}$ \\
\hline \multicolumn{6}{|c|}{ P application $\left(\mathrm{kg} \mathrm{P} \mathrm{ha}^{-1}\right)$} \\
\hline $\mathrm{P} 1(0)$ & $272^{b}$ & $17.36^{\mathrm{a}}$ & $5.06^{\mathrm{b}}$ & $3.31^{b}$ & $407.36^{c}$ \\
\hline P2 (60) & $293^{a}$ & $17.24^{\mathrm{a}}$ & $5.34^{\mathrm{a}}$ & $3.45^{\mathrm{a}}$ & $511.12^{b}$ \\
\hline P3 (90) & $298^{a}$ & $17.57^{\mathrm{a}}$ & $5.25^{\mathrm{a}}$ & $3.42^{\mathrm{a}}$ & $526.84^{a b}$ \\
\hline P4 (120) & $308^{a}$ & $17.60^{\mathrm{a}}$ & $5.30^{\mathrm{a}}$ & $3.49^{a}$ & $555.12^{\mathrm{a}}$ \\
\hline
\end{tabular}

${ }^{\dagger}$ mean values within each treatment $(n=4)$ followed by different letters are significantly different at 0.05 level.

There was a significant $(p<0.01)$ effect interaction for $\mathrm{N} \times \mathrm{P}$ on the increase in the seed yield (Table 1). $\mathrm{N}$ application was beneficial to promoting the effectiveness of $\mathrm{P}$ application on seed yield and yield components (Table 3). At N1, the seed yield and yield components of FS and SS increased significantly $(p<0.05)$ in treatments of P2, P3, and P4 compared with $\mathrm{P} 1$, although there were no significant $(p>0.05)$ differences between $\mathrm{P} 2 / \mathrm{P} 3 / \mathrm{P} 4$ and $\mathrm{P} 1$ at N0. Furthermore, there were no significant $(p>0.05)$ differences among P2, P3, and $\mathrm{P} 4$ at both N0 and N1. Finally, the highest seed yield of smooth bromegrass was obtained with an optimum combination of R2 $(45 \mathrm{~cm}), \mathrm{N} 1\left(100 \mathrm{~kg} \mathrm{P} \mathrm{ha}^{-1}\right)$, and P4 $\left(60 \mathrm{~kg} \mathrm{P} \mathrm{ha}^{-1}\right)$.

Table 3. Effects of $\mathrm{P}$ application on seed yields and seed yield components in smooth bromegrass under certain $\mathrm{N}$ application levels during.

\begin{tabular}{|c|c|c|c|c|c|}
\hline$P$ Treatment (kg P ha-1) & $\begin{array}{l}\text { Fertile Tillers } \mathrm{m}^{-2} \\
\text { (FTs) }\end{array}$ & $\begin{array}{l}\text { Spikelets Per } \\
\text { Fertile Tiller } \\
\text { (SFT) }\end{array}$ & $\begin{array}{c}\text { Florets Per } \\
\text { Spikelet (FS) }\end{array}$ & $\begin{array}{c}\text { Seeds Per } \\
\text { Spikelet (SS) }\end{array}$ & Seed Yield (kg ha $\left.{ }^{-1}\right)$ \\
\hline \multicolumn{6}{|l|}{ N0 (0 kg N ha $\left.{ }^{-1}\right)$} \\
\hline P1 (0) & $195^{\mathrm{a},+}$ & $16.31^{\mathrm{a}}$ & $4.92^{\mathrm{a}}$ & $3.12^{\mathrm{a}}$ & $264.21^{a}$ \\
\hline P2 (60) & $200^{\mathrm{a}}$ & $15.81^{\mathrm{a}}$ & $4.93^{\mathrm{a}}$ & $3.07^{\mathrm{a}}$ & $262.09^{a}$ \\
\hline P3 (90) & $211^{\mathrm{a}}$ & $16.07^{\mathrm{a}}$ & $4.82^{\mathrm{a}}$ & $3.00^{\mathrm{a}}$ & $273.23^{a}$ \\
\hline P4 (120) & $207^{a}$ & $16.16^{\mathrm{a}}$ & $4.92^{\mathrm{a}}$ & $3.12^{\mathrm{a}}$ & $262.22^{a}$ \\
\hline \multicolumn{6}{|l|}{ N1 (100 kg N ha $\left.{ }^{-1}\right)$} \\
\hline P1 (0) & $350^{b}$ & $18.48^{\mathrm{a}}$ & $5.21^{\mathrm{b}}$ & $3.51^{b}$ & $555.94^{b}$ \\
\hline P2 (60) & $390^{\mathrm{a}, \mathrm{b}}$ & $18.70^{\mathrm{a}}$ & $5.78^{\mathrm{a}}$ & $3.84^{\mathrm{a}}$ & $769.48^{a}$ \\
\hline P3 (90) & $385^{\mathrm{a}, \mathrm{b}}$ & $19.05^{\mathrm{a}}$ & $5.69^{\mathrm{a}}$ & $3.83^{\mathrm{a}}$ & $782.49^{a}$ \\
\hline P4 (120) & $409^{\mathrm{a}}$ & $19.03^{\mathrm{a}}$ & $5.67^{\mathrm{a}}$ & $3.85^{\mathrm{a}}$ & $846.27^{a}$ \\
\hline
\end{tabular}

${ }^{\dagger}$ mean values within each treatment $(n=4)$ followed by different letters are significantly different at 0.05 level.

\subsection{Changes of Seed Yield and Yield Components of Smooth Bromegrass during Different Harvested Year}

The data from 2014 to 2018 presented a significant $(p<0.05)$ influence of the harvested year on the seed yield and yield components, and all exhibited the gradually declining trend with the prolonging of the harvested year (Table 4). Interestingly, the FT in 2015 was significantly $(p<0.05)$ lower than those in the other years; while the FS and SS attained the highest level, the seed yield went down to the lowest in 2015. The seed yields harvested in 2014 and 2016 were significantly $(p<0.05)$ higher than those in other years. Since 2017, 
the seed yield began to decline significantly $(p<0.05)$ and was down to the lowest level of $256.96 \mathrm{~kg} \mathrm{ha}^{-1}$ in 2018.

Table 4. Changes in seed yield and seed yield components of smooth bromegrass from 2014 to 2018.

\begin{tabular}{|c|c|c|c|c|c|}
\hline $\begin{array}{l}\text { Harvested } \\
\text { Year }\end{array}$ & $\begin{array}{l}\text { Fertile Tillers } \mathrm{m}^{-2} \\
\text { (FTs) }\end{array}$ & $\begin{array}{l}\text { Spikelets Per } \\
\text { Fertile Tiller } \\
\text { (SFT) }\end{array}$ & $\begin{array}{c}\text { Florets Per } \\
\text { Spikelet (FS) }\end{array}$ & $\begin{array}{c}\text { Seeds Per } \\
\text { Spikelet (SS) }\end{array}$ & Seed Yield (kg ha-1) \\
\hline 2014 & $496^{a, t}$ & $24.48^{\mathrm{a}}$ & $5.12^{b}$ & $3.77^{b}$ & $681.01^{\mathrm{a}}$ \\
\hline 2015 & $170^{d}$ & $17.87^{b}$ & $6.00^{\mathrm{a}}$ & $4.04^{\mathrm{a}}$ & $319.58^{c}$ \\
\hline 2016 & $344^{b}$ & $16.03^{c}$ & $5.10^{b}$ & $2.97^{\mathrm{d}}$ & $758.84^{a}$ \\
\hline 2017 & $227^{c}$ & $14.42^{\mathrm{d}}$ & $5.19^{b}$ & $3.41^{\mathrm{c}}$ & $459.14^{b}$ \\
\hline 2018 & $215^{c}$ & $13.85^{\mathrm{d}}$ & $4.73^{c}$ & $2.83^{d}$ & $256.96^{c}$ \\
\hline
\end{tabular}

${ }^{+}$mean values in each column followed by different letters are significantly different at 0.05 level $(n=128)$.

\subsection{Correlation and Pathway Analysis}

Pathway and correlation analysis were performed for the contribution of row spacing, $\mathrm{N}$, and $\mathrm{P}$ treatments to the seed yield and yield components. The pathway analysis showed that the increased row spacing had a direct negative influence on FTs and a direct positive influence on SFT, FS, and SS (Figure 2). The factor of $\mathrm{N}$ application had a direct positive influence on all the seed yield components, and $\mathrm{P}$ application had a direct positive influence on FS and SS.

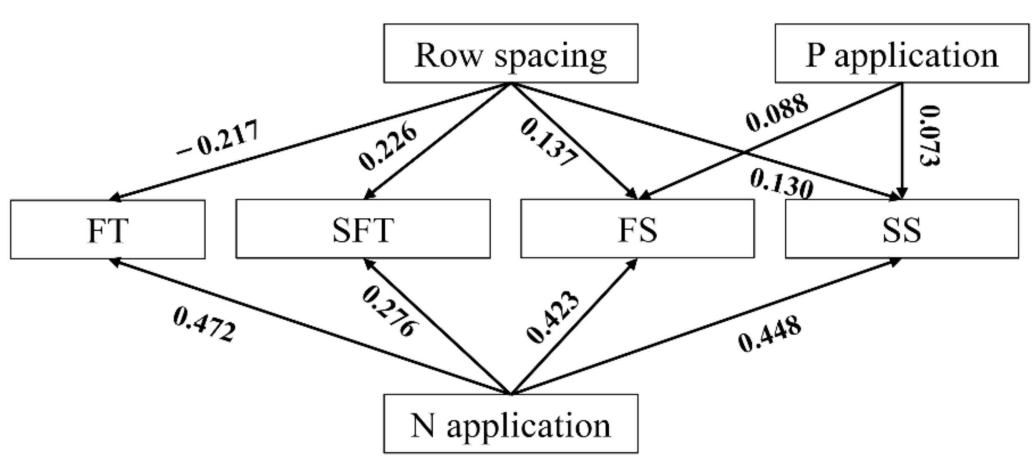

Figure 2. Pathway analysis of row spacing and N/P application on fertile tillers $\mathrm{m}^{-2}$ (FTs), spikelets per fertile tiller (SFT), florets per spikelet (FS), and seeds per spikelet (SS) in smooth bromegrass. The numbers on the lines indicate pathway coefficient.

The correlation analysis showed that the seed yield was extremely significantly $(p<0.01)$ correlated with FTs, SFT, FS, and SS, and the maximum correlation coefficient of 0.744 was achieved for FTs (Table 5). The multiple stepwise regression analysis showed that the FT, FS, and SS made significant $(p<0.05)$ direct contributions to the seed yield with direct pathway coefficients of $0.777,0.434$, and -0.182 , respectively (Table 6 ). Further analysis among the seed yield components showed that the component of SS imposed the strongest indirect influence on seed yield (indirect coefficient $=0.5446$ ), followed by SFT (indirect coefficient $=0.4510$ ). Finally, the structural equation was modeled through pathway analysis as follows: $Z=-715.45+1.56 Y_{1}+205.43 Y_{3}-92.63 Y_{4}$ (Z: seed yield, $Y_{1}$ : FTs, $Y_{2}$ : SFT, $Y_{3}:$ FS, $Y_{4}:$ SS). 
Table 5. Pearson correlation coefficients among seed yield and seed yield components in smooth bromegrass from 2014 to 2018.

\begin{tabular}{|c|c|c|c|c|c|}
\hline $\begin{array}{l}\text { Seed Yield } \\
\text { Components }\end{array}$ & FTs & SFT & FS & SS & Seed Yield (kg ha $\left.{ }^{-1}\right)$ \\
\hline Fertile tillers $\mathrm{m}^{-2}$ (FTs) & 1 & $0.544^{* *}$ & 0.021 & $0.206^{* *}$ & $0.744^{* *}$ \\
\hline $\begin{array}{c}\text { Spikelets per fertile } \\
\text { tiller (SFT) }\end{array}$ & & 1 & $0.278^{* *}$ & $0.507^{* *}$ & 0.461 ** \\
\hline $\begin{array}{l}\text { Florets per spikelet } \\
\text { (FS) }\end{array}$ & & & 1 & $0.847^{* *}$ & $0.294^{* *}$ \\
\hline Seeds per spikelet (SS) & & & & 1 & $0.346^{* *}$ \\
\hline Seed yield $\left(\mathrm{kg} \mathrm{ha}^{-1}\right)$ & & & & & 1 \\
\hline
\end{tabular}

** significant at the 0.01 probability level.

Table 6. Pathway analysis for direct and indirect effects of seed yield components on seed yield in smooth bromegrass.

\begin{tabular}{|c|c|c|c|c|c|c|}
\hline \multirow{2}{*}{$\begin{array}{l}\text { Seed Yield } \\
\text { Components }\end{array}$} & \multirow{2}{*}{$\begin{array}{l}\text { Direct Pathway } \\
\text { Coefficients }\end{array}$} & \multicolumn{5}{|c|}{ Indirect Pathway Coefficients } \\
\hline & & FTs & SFT & FS & SS & Total \\
\hline $\begin{array}{l}\text { Fertile tillers } \mathrm{m}^{-2} \\
\text { (FTs) }\end{array}$ & 0.777 & & 0.0180 & 0.0091 & -0.0375 & -0.0104 \\
\hline $\begin{array}{l}\text { Spikelets per fertile } \\
\text { tiller (SFT) }\end{array}$ & 0.033 & 0.4225 & & 0.1207 & -0.0923 & 0.4510 \\
\hline $\begin{array}{l}\text { Florets per spikelet } \\
\text { (FS) }\end{array}$ & 0.434 & 0.0163 & 0.0092 & & -0.1541 & -0.1287 \\
\hline $\begin{array}{l}\text { Seeds per spikelet } \\
\text { (SS) }\end{array}$ & -0.182 & 0.1600 & 0.0167 & 0.3679 & & 0.5446 \\
\hline
\end{tabular}

\section{Discussion}

\subsection{Effects of Row Spacing and N, P Application on Seed Yield and Yield Components in Smooth Bromegrass}

Seed yield is a quantitative trait influenced by genotype and environment. Seed yield components, such as fertile tillers $\mathrm{m}^{-2}$ (FTs), spikelets per fertile tiller (SFT), florets per spikelet (FS), and seeds per spikelet (SS), are, with direct factors, contributions to seed yield, and affected by rainfall [41], flowering time, growth period, and plant growing rate [42]. In addition, agronomic managements are also important factors affecting the seed yield components [16,24-27].

In terms of seed yield per unit area, the maximum yield is bound to occur in narrow rows generally. In this study, the number of FTs was limited at the wider rows, and the maximum seed yield was achieved at row spacing of $45 \mathrm{~cm}$, while there were no significant differences in the seed yield among row spacing treatments of 30,60 , and $75 \mathrm{~cm}$. A previous study on perennial ryegrass reported that the row spacing from 12 to $48 \mathrm{~cm}$ had a negative effect on FTs but had no effects on seed yield [43]. A compensation effect for seed yield components was observed in smooth bromegrass, as the seed yield with a loss caused by a lowered FT had been rebalanced by the increase in SFT, FS, and SS under wider row spacing (Table 2, Figure 2). It might be explained that wider row spacing provided much light and space for the plants, which resulted in the increase in SS [44] and FS [16,45], albeit a reduction in FTs.

The structural equation model revealed that the seed yield of smooth bromegrass increased by $1.56 \mathrm{~kg} \mathrm{ha}^{-1}$ when the number of FTs increased by each unit. Meanwhile, the seed yield decreased by $92.63 \mathrm{~kg} \cdot \mathrm{ha}^{-1}$ for the increase in one SS unit. Additionally, a significant positive correlation between FTs and SS $(p<0.01)$ was identified under the condition of no nitrogen application, and significant negative correlations were present under $\mathrm{N}$ application (Table 7). These results indicated that the complementary effects 
between FTs and SS could limit the efficiency of nitrogen application. Additionally, the combination of $\mathrm{N}$ and $\mathrm{P}$ application significantly improved the seed yield, mainly through promoting FS and SS and depressing this complementary effect.

Table 7. Correlation analysis of seed yield and yield components in smooth bromegrass under $\mathrm{N}$ application.

\begin{tabular}{|c|c|c|c|c|c|}
\hline $\mathbf{N} 1 \backslash \mathbf{N} 0$ & FTs & SFT & FS & SS & $\begin{array}{c}\text { Seed Yield } \\
\left(\mathrm{kg} \cdot \mathrm{ha}^{-1}\right)\end{array}$ \\
\hline $\begin{array}{l}\text { Fertile tillers } \mathrm{m}^{-2} \\
\text { (FTs) }\end{array}$ & 1 & $0.676^{* *}$ & -0.060 & $0.276^{* *}$ & $0.882 * *$ \\
\hline $\begin{array}{l}\text { Spikelets per fertile } \\
\text { tiller (SFT) }\end{array}$ & $0.264^{* *}$ & 1 & $0.403^{* *}$ & $0.685^{* *}$ & $0.794^{* *}$ \\
\hline $\begin{array}{l}\text { Florets per spikelet } \\
\text { (FS) }\end{array}$ & $-0.361^{* *}$ & -0.020 & 1 & $0.787^{* *}$ & 0.125 * \\
\hline $\begin{array}{l}\text { Seeds per spikelet } \\
\text { (SS) }\end{array}$ & $-0.272^{* *}$ & 0.190 ** & $0.831^{* *}$ & 1 & $0.432 * *$ \\
\hline $\begin{array}{c}\text { Seed yield } \\
\left(\mathrm{kg} \cdot \mathrm{ha}^{-1}\right)\end{array}$ & $0.563 * *$ & $0.152 * *$ & 0.011 & -0.074 & 1 \\
\hline
\end{tabular}

${ }^{*}$ significant at the 0.05 probability level, ${ }^{* *}$ significant at the 0.01 probability level.

\subsection{Effects of Local Climate and Harvest Year in Seed Yield and Yield Components of Smooth Bromegrass}

In addition to nutrient requirements, temperature and water are also important factors to influence seed yield. Suitable temperature and precipitation are the basic requirements for the vegetative and reproductive growth of forage plants in arid and semi-arid regions. Only after a period of low temperature (vernalization), can the tillers of smooth bromegrass develop into fertile tillers [46]. The growth and development of plants are greatly affected by the amount and distribution of precipitation [47]. The mean monthly temperature from 2013 to 2018 was relatively stable in our field (Figure 1). The total precipitation at the growing season was relatively stable from 2013 to 2017, as the total precipitation in the non-growing seasons (i.e., from August to April of the following year) varied from $97.2 \mathrm{~mm}$ in 2015 to $203.9 \mathrm{~mm}$ in 2017. Interestingly, with the least precipitation in the non-growing season in 2015, the lowest seed yield was harvested (Table 4), which was mainly due to the insufficient FTs. Therefore, it was important for the grower to pay attention to the variation of precipitation in the seed field under rain-fed conditions.

The FT mainly depends on the tillers that came out in the previous year. The declining FT number in 2015 might be caused by the lower amount of precipitation from August to October in 2014. It was also found that precipitation in the post harvesting stage was helpful for the FT formation of sheepgrass (Leymus chinensis L.) in the next year [48]. In addition, with stand age prolonged in seed fields, there was similar declining tendency of seed yield for some perennial grasses. In this study, we found that the seed yield of smooth bromegrass began to decline significantly $(p<0.05)$ after the third harvested year, which was consistent with the previous reports on slender wheatgrass (Elymus trachycaulus L.), smooth bromegrass, and Siberian wildrye $[16,45]$. The seed yield components also presented a gradual decreasing tendency with the prolonging of stand age.

\subsection{Relationship between Seed Yield and Yield Components in Smooth Bromegrass}

As there were significant $(p<0.05)$ correlations among the seed yield components, simple linear regression analysis was not accurate to determine a single important component correlated with seed yield. Path analysis is a good way to determine the relationship between the seed yield and the yield components. It divides the total effects into direct and indirect ones and provides determination coefficients of each seed yield component [49]. Our results of path analysis revealed that FTs, significantly affected by nitrogen application and row spacing, had strong direct effects on seed yield in smooth bromegrass. It was consistent with the previous studies on smooth bromegrass [50] and Russian wildrye [5]. 
Interestingly, the direct effects of FS and SS on seed yield were positive and negative, respectively. The negative effect of SS on seed yield might be partly related to FTs. SS was correlated positively and negatively with FTs under N0 and N1, respectively. This relationship might be partly explained by the competition of photoassimilates between stem and ear [51].

There were complementary effects among the seed yield components to maintain the seed yield of smooth bromegrass. When the seed yield of smooth bromegrass was influenced by precipitation or other agronomic practices, the complementary effects of the seed yield components were always employed to balance the seed yield.

\section{Conclusions}

Fertile tillers $\mathrm{m}^{-2}$ was the primary factor to determine seed yield in smooth bromegrass. Meanwhile, there were interaction effects between fertile tillers $\mathrm{m}^{-2}$ and seeds per spikelet. Therefore, a combination of seed yield components should be selected to promote seed production, rather than using one or two. Fertile tillers $\mathrm{m}^{-2}$ was significantly affected by row spacing, $\mathrm{N}$ application, and precipitation in the post harvesting stage, while seeds per spikelet were significantly affected by $\mathrm{P}$ application. The optimum seed yield in smooth bromegrass under rain-fed conditions was obtained with row spacing $(45 \mathrm{~cm})$, nitrogen application (100 kg P ha $\left.{ }^{-1}\right)$, and phosphorus application $\left(60 \mathrm{~kg} \mathrm{P} \mathrm{ha}^{-1}\right)$.

Author Contributions: C.O. analyzed the data and wrote the manuscript; M.W. designed and performed the experiments and revised the manuscript; P.M. designed and supervised the research and edited the manuscript; L.H., Y.Z., and C.O. were involved in performing the experiments; M.S. and S.S. were involved in data analysis; and S.J. edited the manuscript. All authors have read and agreed to the published version of the manuscript.

Funding: This research was funded by the China Agriculture Research System of MOF and MARA, and Beijing Common Construction Project.

Data Availability Statement: Not applicable.

Conflicts of Interest: The authors declare no conflict of interest.

\section{References}

1. Young, W.C.; Youngberg, H.W.; Silberstein, T.B. Management studies on seed production of turf-type tall fescue: II. Seed yield components. Agron. J. 1998, 90, 478-483. [CrossRef]

2. Deleuran, L.C.; Kristensen, K.; Gislum, R.; Boelt, B. Optimizing the number of consecutive seed harvests in red fescue (Festuca rubra L.) and perennial ryegrass (Lolium perenne L.) for yield, yield components and economic return. Acta Agric. Scand. Sect. B-Soil Plant Sci. 2013, 63, 1-10. [CrossRef]

3. Cookson, W.R.; Rowarth, J.S.; Cameron, K.C. The response of a perennial ryegrass (Lolium perenne L.) seed crop to nitrogen fertilizer application in the absence of moisture stress. Grass Forage Sci. 2000, 55, 314-325. [CrossRef]

4. Seker, H.; Serin, Y. Explanation of the relationships between seed yield and some morphological traits in smooth bromegrass (Bromus inermis Leyss.) by path analysis. Eur. J. Agron. 2004, 21, 1-6. [CrossRef]

5. Wang, Q.; Zhang, T.; Cui, J.; Wang, X.; Zhou, H.; Han, J.; Gislum, R. Path and ridge regression analysis of seed yield and seed yield components of Russian wildrye (Psathyrostachys juncea Nevski) under field conditions. PLoS ONE 2011, 6, e18245. [CrossRef]

6. Wang, M.; Hou, L.; Zhang, Q.; Yu, X.; Zhao, L.; Lu, J.; Mao, P.; Hannaway, D.B. Influence of row spacing and P and N applications on seed yield components and seed yield of Siberian wildrye (Elymus sibiricus L.). Crop Sci. 2017, 57, 2205-2212. [CrossRef]

7. Bugge, G. Selection for Seed Yield in Lolium perenne L. Plant Breed. 1987, 98, 149-155. [CrossRef]

8. Byrne, S.; Guiney, E.; Barth, S.; Donnison, I.; Mur, L.A.J.; Milbourne, D. Identification of coincident QTL for days to heading, spike length and spikelets per spike in Lolium perenne L. Euphytica 2008, 166, 61-70. [CrossRef]

9. Hampton, J.G. Effect of nitrogen rate and time of application on seed yield in perennial ryegrass cv. Grasslands Nui. N. Z. J. Exp. Agric. 1987, 15, 9-16. [CrossRef]

10. Walter, A.; Studer, B.; Kölliker, R. Advanced phenotyping offers opportunities for improved breeding of forage and turf species. Ann. Bot. 2012, 110, 1271-1279. [CrossRef]

11. Abel, S.; Boelt, B. Precipitation during anthesis reduces seed set in perennial ryegrass. Grass Forage Sci. 2017, 73, $239-246$. [CrossRef]

12. Rolston, P.; Trethewey, J.; Chynoweth, R.; Mccloy, B. Trinexapac-ethyl delays lodging and increases seed yield in perennial ryegrass seed crops. N. Z. J. Agric. Res. 2010, 53, 403-406. [CrossRef] 
13. Raey, Y.; Ghassemi-Golezani, K. Yield density relationship for potato (Solarium tuberosum) and common bean (Phaseolus vulgaris) in intercropping. N. Z. J. Crop. Hortic. Sci. 2009, 37, 141-147. [CrossRef]

14. Khan, S.; Anwar, S.; Kuai, J.; Ullah, S.; Fahad, S.; Zhou, G. Optimization of nitrogen rate and planting density for improving yield, nitrogen use efficiency, and lodging resistance in oilseed rape. Front. Plant Sci. 2017, 8, 532. [CrossRef]

15. Fairey, N.A.; Lefkovitch, L.P. Crop density and seed production of tall fescue (Festuca arundinacea Schreber). 1. Yield and plant development. Can. J. Plant Sci. 1999, 79, 535-541. [CrossRef]

16. Han, Y.; Wang, X.; Hu, T.; Hannaway, D.B.; Mao, P.; Zhu, Z.; Wang, Z.; Li, Y. Effect of row spacing on seed yield and yield components of five cool-season grasses. Crop Sci. 2013, 53, 2623-2630. [CrossRef]

17. Cameron, K.C.; Di, H.J.; Moir, J.L. Nitrogen losses from the soil/plant system: A review. Ann. Appl. Biol. 2013, 162, 145-173. [CrossRef]

18. LeBauer, D.S.; Treseder, K.K. Nitrogen limitation of net primary productivity in terrestrial ecosystems is globally distributed. Ecology 2008, 89, 371-379. [CrossRef]

19. Vidal, E.A.; Moyano, T.C.; Canales, J.; Gutierrez, R.A. Nitrogen control of developmental phase transitions in Arabidopsis thaliana. J. Exp. Bot. 2014, 65, 5611-5618. [CrossRef]

20. Singh, N.; Pal, N.; Mahajan, G.; Singh, S.; Shevkani, K. Rice grain and starch properties: Effects of nitrogen fertilizer application. Carbohydr. Polym. 2011, 86, 219-225. [CrossRef]

21. Tanaka, A.; Toriyama, K.; Kobayashi, K. Nitrogen supply via internal nutrient cycling of residues and weeds in lowland rice farming. Field Crops Res. 2012, 137, 251-260. [CrossRef]

22. Zhang, Q. Strategies for developing green super rice. Proc. Natl. Acad. Sci. USA 2007, 104, 16402-16409. [CrossRef] [PubMed]

23. Ju, X.T.; Xing, G.X.; Chen, X.P.; Zhang, S.L.; Zhang, L.J.; Liu, X.J.; Cui, Z.L.; Yin, B.; Christie, P.; Zhu, Z.L.; et al. Reducing environmental risk by improving $\mathrm{N}$ management in intensive Chinese agricultural systems. Proc. Natl. Acad. Sci. USA 2009, 106, 3041-3046. [CrossRef] [PubMed]

24. Satyanarayana, V.; Vara Prasad, P.V.; Murthy, V.R.K.; Boote, K.J. Influence of integrated use of farmyard manure and inorganic fertilizers on yield and yield components of irrigated lowland rice. J. Plant Nutr. 2002, 25, 2081-2090. [CrossRef]

25. Pandey, R.; Maranville, J.; Admou, A. Tropical wheat response to irrigation and nitrogen in a Sahelian environment. I. Grain yield, yield components and water use efficiency. Eur. J. Agron. 2001, 15, 93-105. [CrossRef]

26. Shi, Y.; Gao, S.; Zhou, D.; Liu, M.; Wang, J.; Knops, J.M.H.; Mu, C. Fall nitrogen application increases seed yield, forage yield and nitrogen use efficiency more than spring nitrogen application in Leymus chinensis, a perennial grass. Field Crops Res. 2017, 214, 66-72. [CrossRef]

27. Wang, J.; Li, X.; Gao, S.; Li, Z.; Mu, C. Impacts of fall nitrogen application on seed production in, a rhizomatous perennial grass. Agron. J. 2013, 105, 1378-1384. [CrossRef]

28. Batten, G.D. A review of phosphorus efficiency in wheat. Plant Soil 1992, 146, 163-168. [CrossRef]

29. Torabi, S.; Wissuwa, M.; Heidari, M.; Naghavi, M.R.; Gilany, K.; Hajirezaei, M.R.; Omidi, M.; Yazdi-Samadi, B.; Ismail, A.M.; Salekdeh, G.H. A comparative proteome approach to decipher the mechanism of rice adaptation to phosphorous deficiency. Proteomics 2009, 9, 159-170. [CrossRef]

30. Usuda, H.; Shimogawara, K. Phosphate deficiency in maize: III. Changes in enzyme activities during the course of phosphate deprivation. Plant Physiol. 1992, 99, 1680-1685. [CrossRef]

31. Berg, W.K.; Cunningham, S.M.; Brouder, S.M.; Joern, B.C.; Johnson, K.D.; Santini, J.; Volenec, J.J. Influence of phosphorus and potassium on alfalfa yield and yield components. Crop Sci. 2005, 45, 297-304. [CrossRef]

32. Liao, H.; Rubio, G.; Yan, X.; Cao, A.; Brown, K.M.; Lynch, J.P. Effect of phosphorus availability on basal root shallowness in common bean. Plant Soil 2001, 232, 69-79. [CrossRef]

33. Cheema, M.A.; Malik, M.A.; Hussain, A.; Shah, S.H.; Basra, S.M.A. Effects of time and rate of nitrogen and phosphorus application on the growth and the seed and oil yields of canola (Brassica napus L.). J. Agron. Crop Sci. 2001, 186, 103-110. [CrossRef]

34. Xie, Y.; Niu, J.; Gan, Y.; Gao, Y.; Li, A. Optimizing phosphorus fertilization promotes dry matter accumulation and P remobilization in oilseed flax. Crop Sci. 2014, 54, 1729-1736. [CrossRef]

35. Loeppky, H.A.; Horton, P.R.; Bittman, S.; Townley-Smith, L.; Wright, T.; Nuttall, W.F. Forage seed yield response to N and P fertilizers and soil nutrients in northeastern Saskatchewan. Can. J. Soil Sci. 1999, 79, 265-271. [CrossRef]

36. Salesman, J.B.; Thomsen, M. Smooth brome (Bromus inermis) in tallgrass prairies: A review of control methods and future research directions. Ecol. Restor. 2011, 29, 374-381. [CrossRef]

37. Saeidnia, F.; Majidi, M.M.; Mirlohi, A.; Bahrami, S. Inheritance and combining ability of persistence and drought recovery in smooth bromegrass (Bromus inermis L.). Euphytica 2019, 215, 177. [CrossRef]

38. Acikgoz, E.; Tekeli, A.S. Seed yield and its components in smooth bromegrass (Bromus inermis L.) cultivars. Euphytica 1980, 29, 199-203. [CrossRef]

39. Mao, P.; Han, J.; Wang, P.; Rong, Y. Effects of fertilizer application on seed yield of smooth bromegrass and Siberian wildrye. Acta Agrestia Sin. 2000, 8, 273-278. [CrossRef]

40. Sun, T.; Han, J.; Zhao, S.; Yue, W. Effect of fertilizer application on seed yield and yield components of Bromus inermis. Acta Pratac. Sin. 2005, 14, 84-92. [CrossRef]

41. Duggan, B.L.; Domitruk, D.R.; Fowler, D.B. Yield component variation in winter wheat grown under drought stress. Can. J. Plant Sci. 2000, 80, 739-745. [CrossRef] 
42. Li, R.; Li, M.; Ashraf, U.; Liu, S.; Zhang, J. Exploring the relationships between yield and yield-related traits for rice varieties released in China from 1978 to 2017. Front. Plant Sci. 2019, 10, 543. [CrossRef]

43. Deleuran, L.C.; Gislum, R.; Boelt, B. Cultivar and row distance interactions in perennial ryegrass. Acta Agric. Scand. Sect. B-Soil Plant Sci. 2009, 59, 335-341. [CrossRef]

44. Schillinger, W.F.; Wuest, S.B. Wide row spacing for deep-furrow planting of winter wheat. Field Crops Res. 2014, 168, 57-64. [CrossRef]

45. You, M.; Liu, J.; Bai, S.; Lin, D.; Yan, J.; Zhang, C. Influence of row spaces and planting years on yield of fresh grass and seeds of Elymus sibiricus. Pratac. Sci. 2012, 29, 1278-1284.

46. Li, Q.; Wang, F. Meteorological analysis for seed production in northern China. J. Arid Land Resour. Environ. 2001, 15, 93-96. [CrossRef]

47. Bai, Y.; Wu, J.; Xing, Q.; Pan, Q.; Huang, J.; Yang, D.; Han, X. Primary production and rain use efficiency across a precipitation gradient on the Mongolia plateau. Ecology 2008, 89, 2140-2153. [CrossRef]

48. Wang, J.F.; Xie, J.F.; Zhang, Y.T.; Gao, S.; Zhang, J.T.; Mu, C.S. Methods to improve seed yield of based on nitrogen application and precipitation analysis. Agron. J. 2010, 102, 277-281. [CrossRef]

49. Iannucci, A.; Fonzo, N.D.; Martiniello, P. Alfalfa (Medicago sativa L.) seed yield and quality under different forage management systems and irrigation treatments in a Mediterranean environment. Field Crops Res. 2002, 78, 65-74. [CrossRef]

50. Wang, Q.; Cui, J.; Wang, X.; Zhang, T.; Zhou, H.; Hu, T.; Han, J. Algorithmic models of seed yield and its components in smooth bromegrass (Bromus inermis L.) via large sample size under field conditions. Euphytica 2012, 185, 363-375. [CrossRef]

51. Wang, M.; Hou, L.; Zhu, Y.; Zhang, Q.; Wang, H.; Xia, F.; Chen, L.; Mao, P.; Hannaway, D.B. Siberian wildrye seed yield limited by assimilate source. Field Crops Res. 2018, 218, 18-23. [CrossRef] 